Research on retention of students of color suggests possible areas of intervention to improve academic success.

\title{
Key Issues in the Persistence of Underrepresented Minority Students
}

\author{
Deborah Faye Carter
}

There is a gap between ethnic minority students and ethnic majority students in the attainment of higher education degrees (Allen, 1992; DesJardins, Ahlburg, and McCall, 2002; Hatch and Mommsen, 1984; Mehan, Hubbard, and Villanueva, 1994; Myers, 2003; Pathways to College Network, 2003). Racial or ethnic minority students have a higher probability of leaving postsecondary education than ethnic majority students. This is a serious, longterm problem, as there are growing numbers of students of color in the K-12 student population and they disproportionately are not graduating from college (Keller, 2001; Pascarella and Terenzini, 1998). The Pathways to College Network (2003) reports that when comparing groups of individuals in their late twenties, more than one-third of whites have at least a bachelor's degree, but only 18 percent of African Americans and 10 percent of Hispanics have attained bachelor's degrees.

The gap between underrepresented minority students and other groups is particularly detrimental because it affects individuals' long-term social mobility. The attainment of any postsecondary degree (particularly a baccalaureate degree) often results in a greater net dividend for minority populations (Malveaux, 2003). For example, the median African American family income is 63 percent of the median white family income ("Holding a Four-Year College Degree," 2005). If income data are analyzed only for individuals who received baccalaureate degrees, however, African Americans on average earn 95 percent of what white individuals earn ("Holding," 2005).

\section{(\$)WILEY}

\section{InterScience ${ }^{\circ}$}


These statistics highlight the necessity of understanding retention issues, especially for underrepresented students. Understanding student retention is not only important for campus leaders, practitioners, and researchers, but it also has long-term effects on society. Nearly twenty years ago, Stewart (1988) asserted that the most urgent need in higher education was the successful participation or retention of minority students. This observation remains true today.

This chapter reviews the general literature relating to the academic success and persistence of minority students. The issues covered in this chapter are of particular interest to institutional researchers for several reasons. First, institutional research (IR) professionals may be called upon or be interested in analyzing student performance (for example, academic achievement, persistence, and retention issues) by racial or ethnic group. Second, institutional administrators may be interested in increasing racial or ethnic diversity in their student populations; the expertise of IR professionals can be critical in assisting with these goals. Data produced in institutional research offices can help ascertain why students from different regions or sociocultural backgrounds choose to attend a particular institution, what academic majors they pursue, and the impact of financial aid on persistence and other educational outcomes.

In this chapter, I begin with a discussion of a statewide study of college student retention issues. The rest of the chapter reviews important literature streams that are generally relevant to understanding retention issues and specifically relevant for underrepresented minority students. The chapter concludes with a discussion of implications for future research.

\section{Retention in a State Context}

St. John, Carter, Chung, and Musoba (forthcoming) examined the factors affecting African American, Hispanic, and white students' persistence at public and private institutions in Indiana. The results of the study revealed substantial similarities and a few very important differences in the factors that influence the persistence of the three racial or ethnic groups. The differences between groups are most easily understood if viewed in relation to differences in the situated contexts of the lives of college students, an alternative to the more usual vantage point of seeking to uncover universal patterns across groups of students (Braxton, 2000; Pascarella and Terenzini, 1991). By uncovering differences in persistence patterns across diverse groups, we can illuminate factors that inhibit equal opportunity as well as policy factors that might be able to improve opportunity.

First, background variables were associated with persistence for all three groups in the St. John study, but with substantially different patterns. For whites, having parents who had not attained a college education decreased the odds of academic success in college, while being from families with high incomes improved these odds. For Hispanics and African 
Americans, high income was a positive factor, but parents' education was not significant. For the three groups, there was a strong relationship between socioeconomic status and student persistence in college. For African Americans and Hispanics, having an adequate aid guarantee enabled students to overcome the barriers related to parents' education and income, a condition that is not met nationally.

A second major area of the study was the role of high school curricula in student persistence rates. The Indiana state context plays a role in how students persist: the study took place in a state that has made an effort to place college preparatory curricula in all high schools. For all three groups, completing preparatory or honors curricula had a sustained positive influence on persistence. High school grades did not have as substantial an influence for white students and had no significant relationship for African American or Hispanic students, indicating that a main academic effort for increasing persistence for students of color may be in the area of increasing the availability of advanced courses.

Third, increasing the availability of advanced courses not only has an effect on college student persistence, but taking advanced courses is associated with high SAT scores in Indiana. However, the effect of taking the SAT had little impact on student persistence for any group. The lack of significance of the SAT on students' college persistence may be because this study took place in a state in which the majority of high school students take the SAT.

Fourth, college choices influenced persistence for white and African American students. Attending state universities, private colleges, and research universities was consistently and positively associated with persistence compared to enrollment in two-year colleges; on the other hand, attending regional campuses, the urban campus, and private colleges did not have this positive association for whites.

There were substantial differences in the association between choice of major and persistence across the three groups. For whites, having a declared major was consistently and positively associated with persistence. However, for African Americans, several academic majors were negatively associated with persistence, and there were no positive associations. These findings raise questions about engagement in academic programs and whether the content of majors meets the expectations of African Americans. Faculties in health, business, education, and computer science in particular need to consider why their majors do not support persistence by diverse students.

In addition to major, there were many common patterns in the effects of college experiences across the three sets of analyses. High college grades were positively associated with persistence and low grades were negatively associated with this outcome in all three analyses. In addition, taking remedial courses in both language and math were consistently and positively associated with persistence. This means that achievement is important, but support services can help students who have special additional needs. 
Finally, there were differences in the effects of student financial aid across racial or ethnic groups in the state, at least for the entering collegiate class of 2000. For whites and Hispanics there were no significant financial aid variables, suggesting aid may be helping to equalize opportunity, yet high-income students were more likely to persist in all three ethnic groups. Specifically, for African Americans, a group with a high percentage of lowincome students, all types of packages with grant aid, including loans and grants, were positively associated with persistence. For Hispanics, receiving packages with work-study substantially improved the odds of persistence, a pattern consonant with a working-class pattern of student choice.

It is apparent that public finance policies do influence different groups in different ways. Because of their high poverty rate in the state, African Americans can benefit from the state's achievement program more than whites. Further, excessive loans can be problematic for middle-income families, who may question whether their expected earnings will grow sufficiently to justify continued borrowing. At the very least, these differences merit further and wider consideration, given the ongoing challenges facing educational opportunity for high-achieving students of color.

\section{Tinto's Model}

Tinto's model of student departure $(1982,1993)$ has been the theoretical framework used most often in examining the predictors of attainment and persistence. Building on the research of Spady $(1970,1971)$, Tinto proposed a model of student departure that was initially based on the sociological concept of suicide as proposed by Durkheim (1951). Tinto (1993) incorporated Van Gennep's ideas regarding rites of passage (Van Gennep, 1960, as cited by Tinto [1993]) into adulthood in tribal societies into his model in later explorations of student departure. He drew analogies between the concepts of suicide and the passage to adulthood and college student dropout and persistence.

Research using Tinto's framework has contributed a great deal to the understanding of what affects student dropout or departure and student persistence. Several researchers have recognized the utility of the Tinto model in predicting college student attrition (Getzlaf, Sedlacek, Kearney, and Blackwell, 1984; Pascarella and Terenzini, 1980). Tinto (1993) proposed that the occurrence of college student departure provides a window on the social and academic communities in which students experience colleges and universities.

\section{Perspectives on Tinto's Model}

Researchers have built on Tinto's model and have offered a variety of different perspectives through which to examine student departure. Some have proposed an examination of student attrition through an organizational per- 
spective. Bean (1980) challenged Tinto's ideas of tying student departure to suicide and proposed that researchers interested in student departure turn to organizational studies that have examined why individuals leave work or group settings. More recently, Bean and Eaton (2000), claiming that the factors affecting retention are related to individual psychological processes involved in developing academic and social integration, developed a psychological model of college student retention. Examples of successful retention programs are learning communities, first-year interest groups, tutoring, mentoring, and student orientation (Myers, 2003).

Over the years, researchers have challenged Tinto's model for its limited applicability to minority students (Braxton, Sullivan, and Johnson, 1997; Tierney, 1992). The researchers have asked those studying student departure to examine carefully the applicability of the Tinto model to the variety of students that are part of higher education today.

Braxton and his colleagues (1997) addressed the fifteen testable propositions derived from Tinto's model in terms of aggregated support, support by institutional type, and support by student group. They proposed that, in the future, researchers may want to assess the fifteen propositions using different student racial or ethnic groups. According to these researchers, "the empirical internal consistency of Tinto's theory is indeterminate for both African Americans and Native Americans/Alaskan natives" (p. 158). They suggested engaging in theory revision or using other theoretical perspectives for studying the retention of racial or ethnic minority-group members.

Tierney (1992) disagrees with the adaptation of anthropological concepts—such as the rituals of transition-into the Tinto model. According to Tierney, "Rituals of transition have never been conceptualized as movements from one culture to another" (p. 611). He maintained that the Tinto model makes assumptions regarding individuals undergoing a rite of passage in a culture that may or may not be their own (such as minority students within white institutions). An additional challenge extended by Tierney is that "essentially, models of integration have the effect of merely inserting minorities into a dominant cultural frame of reference that is transmitted within dominant cultural forms, leaving invisible cultural hierarchies intact" (p. 611).

As a counter to the assumption of integration, in recent years researchers have tried to offer different conceptions of the process by which minority students can successfully navigate predominantly white college environments. Rendón, Jablomo, and Nora (cited in Swail, Redd, and Perna, 2003) describe the process of biculturation whereby students "live simultaneous lives in two cultures, two realities" (p. 49). Troy Duster (also cited in Swail) describes a similar phenomenon as "dual competency" in that "students must be competent in their own culture plus the culture of the institution" (p. 49). 


\section{Academic Characteristics}

Twenty-five years ago, Thomas (1981) identified some key issues for increasing African American student access and retention in college. High schools, Thomas contended, need to identify earlier and properly support a greater number of college-bound African American students and employ "constructive and earlier use of competency-based testing" (p. 382). Her final recommendation for increasing access to four-year colleges was to increase the role of two-year institutions in promoting the transfer function to four-year institutions and helping students of color have some additional time after high school graduation to increase academic preparation. Thomas's conclusions are similar to the conclusions of researchers in the twenty-first century. Progress has been made in the last two decades, but not nearly as much progress as is needed.

Lavin and Crook (1990) examined ethnic differences in long-term educational attainment and found that minority students demonstrated less academic success all along the way and were far more likely than whites to leave college without any degree. They found that half of the African American and Hispanic students attending community colleges never earned any credentials. African American and Hispanic students receiving diplomas were more likely to earn associate degrees than were whites. In addition, 40 percent of whites went beyond the associate level compared to one-third of African Americans and Hispanics. The authors also found that it typically took minority students longer to earn an undergraduate degree. They concluded that a process of cumulative disadvantage is occurring that is partially derived from differences in high school experience. African Americans and Hispanics reported receiving lower grades in high school and more often came from nonacademic high school tracks.

Allen, Bonous-Hammarth, and Suh (2004) studied student high school preparation, college choice, and factors contributing to college enrollment for students of color. Through the use of quantitative analyses and focus group interviews, the authors "remind[ed] us that educational achievement is a social process, shaped by human exchanges within definitive sociocultural contexts" (p. 96). For example, students described a "tracking" phenomenon whereby students who were designated "smart" were prepared for college, received mentors, and experienced college tours, while the other students received very little assistance in their plans for postsecondary education.

Many students of color experience structural disadvantages, but there are campus academic experiences that affect student outcomes in a positive manner. Hurtado (2001) describes research that links student classroom experiences with diversity-related outcomes. Interaction with diverse student peers and with diverse faculty produce self-reported increases in students' critical thinking skills and writing ability. Hurtado's work has implications for how college campuses structure their classroom learning environments. Colleges can take advantage of peer diversity and 
train faculty in a variety of pedagogies that can positively affect student outcomes.

\section{College Experiences}

Several studies have been done of African American students using surveys and quantitative data analyses. These studies have contributed a great deal of knowledge about the general experiences of African American students across different kinds of colleges and universities, specifically the different experiences of African American students at predominantly white institutions (PWIs) and at historically black colleges and universities (HBCUs).

African American students experience exclusion, racial discrimination, and alienation on predominantly white campuses (Allen, 1992; Turner, 1994). In contrast, at HBCUs, African Americans "emphasize feelings of engagement, connection, acceptance, and . . encouragement" (Allen, 1992, p. 39). Feagin, Vera, and Imani (1996) detailed some of the negative experiences African Americans have at PWIs. In brief, the African American students felt that white faculty, students, and staff did not view them as "full human beings with distinctive talents, virtues, interests, and problems" (p. 14). Black students at PWIs often feel anxiety and fear at being the only one or one of a few African Americans in a particular environment (Smedley, Myers, and Harrell, 1993). This anxiety can mean that African Americans look for the increased company of other African Americans for their support. Feagin and colleagues also reported that "a recent survey of black students at mostly white universities found they were so concerned about intellectual survival that they were unable to devote as much attention to their personal, social, and cultural development as they should" (p. 75).

Shom and Spooner (1990) investigated several precollegiate programs (for example, Upward Bound and Early Outreach) and concluded that several questions remain regarding the continuing commitment by colleges and universities to monitor and support the educational and maturational progress of the participants and the continuing investment of funds into programs that are involved in this broad initiative of precollegiate programs. They wondered "if this initiative is a case of too little too late to keep pace with the rising tide of minorities who are not being adequately prepared for or stimulated toward a fulfilling experience" (p. 228).

Smedley, Myers, and Harrell (1993) were concerned with the strains of the student role and the stresses of life events and minority status that may affect a student's successful psychological and academic adjustment to college. They report that the "more debilitating minority status stressors were those that undermined students' academic confidence and ability to bond to the university" (p. 448). They found that these stresses come from internal sources as well as from the social climate and composition of the institution. 
In a study that supports Smedley's research, Bynum and Thompson (1983) examined the issues of student departure at four different institutions. Their findings indicate that students of any race (Native American, African American, or white) who are in the minority on campus are more likely to drop out of college prior to graduation than students in the racial majority.

An inclusive and welcoming institutional environment and the connection of students to that environment have been linked to persistence. Hurtado, Milem, Clayton-Pederson, and Allen (1998) found that the campus climate, or the institutional environment with respect to inclusion, affects the retention of students. According to Kuh (1995), students' connection to the campus environment, often called student engagement, and student involvement are important factors in retaining students. Students who engage on campus may take advantage of more opportunities to secure academic membership and ultimately improve chances of persistence (BonousHammarth, 2000).

Students' in-college experiences have been shown to affect their adjustment to and persistence in college more than do their backgrounds (Hurtado, Carter, and Spuler, 1996). This finding provides hope that retention programs may work to overcome some of the disadvantages of student backgrounds. In a comprehensive review of retention programs, Myers (2003) asserted that the institutional environment has a powerful impact on students' satisfaction with and success in an institution. He elaborated that the institutions that are successful in retaining students are those that are responsive to the academic, social and cultural needs of their students. Tinto (1993) concludes that successful retention programs are longitudinal, are tied to the admissions process, and involve a wide range of institutional actors.

The work of other researchers has also contributed to an understanding of the process of degree attainment. Astin, Tsui, and Avalos (1996) completed a study examining bachelor's degree attainment rates by institutional type. They found that private colleges and universities had significantly higher degree attainment and retention rates than public institutions. They conclude that there are structural elements of postsecondary institutions that independently affect students' attainment levels—despite precollege academic performance levels.

To improve retention, many programs have been successfully employed, among them advising, counseling, tutoring, basic skills development, firstyear orientation (Boudreau and Kromrey, 1994), faculty involvement, study skills courses, test-taking clinics, and career advising. Also, residence halls and learning communities on college campuses have demonstrated positive effects on student persistence (Astin, 1993; Berger, 2000; Tinto, 1993).

\section{Student Financial Aid}

Access to college and retention in college are two distinct concepts that have been linked in recent research. St. John, Paulsen, and Starkey (1996) 
first developed the concept of linking issues of access and retention relative to financial aid, and these concepts were expanded in St. John, Paulsen, and Carter (2005). These researchers argued that students choose colleges because of financial reasons and that these financial reasons and the actual college prices have impacts on their college experiences which, in turn, affect persistence. In other words, there is a nexus between students' financial reasons for attending college and their subsequent persistence behavior.

Berger (2000) examined students' patterns of college decision making and related these patterns to socioeconomic status (SES). Indeed, students from different SES groups responded differently to financial aid. Lowincome students were more likely to drop out if their levels of grant aid were insufficient, and working-class students were more likely to drop out if their amounts of work-study and loans were not adequate (Paulsen and St. John, 2002).

Previous analyses of differences among racial groups with regard to student aid indicated that African Americans were less likely to persist if financial aid levels were not adequate (Kaltenbaugh, St. John, and Starkey, 1999). In addition, research has indicated that students' college choices are constrained by their social circumstances. For instance, lower SES students tend to be constrained by their financial circumstances in that they attend less expensive institutions closer to their homes (Carter, 1999). This is particularly true for Hispanics, who proportionally have much higher two-year college-going rates than other races or ethnicities.

In addition, researchers have frequently studied the degree to which race and social class affect student access to college. Researchers have concluded that class-more than race-affects student college-going opportunities (Hanson, 1994; Hearn, 1984). However, there are also important racial differences in college access.

An American Council on Education (ACE) study of the "public's knowledge and attitudes about financing higher education" showed that people do not understand the differences between public and private institutions or two-year and four-year colleges (Hartle, 1998). Seventy-one percent of the people surveyed believe that college is not affordable for most families, and 83 percent of the African American respondents believe so.

Recent analyses raise doubts that more information will solve the access problem. The Advisory Committee on Student Financial Assistance (2002) estimates that four million college-qualified low-income and middle-income students will be left behind in the next decade. If finances are a problem in enrollment and persistence, then it is even more important to examine these differences for diverse racial and ethnic groups.

Financial constraints also play a role in attrition (Pathways to College Network, 2003; St. John, 1994). Only one-quarter of low-income students who enroll in postsecondary education actually receive bachelor's degrees (Pathways to College Network, 2003). Financial aid, especially grants, has 
also been shown to promote persistence. The financial nexus model links college choice and persistence with financial background and need (Paulsen and St. John, 2002). This model asserts that students' perceptions of college costs and the actual dollar amount of costs and aid may affect persistence decisions.

Higher education researchers have shown the enduring effects of SES on college student outcomes (Hearn, 1991). A student's SES is a significant predictor of the type of higher education institution he or she can attend (Pascarella, Smart, and Smylie, 1992). Cabrera, Stampen, and Hansen (1990) addressed the issue of ability to pay on college persistence by expanding Tinto's model by "explicating the potential moderating effects of ability to pay on college persistence" (p. 326). They concluded that ability to pay has a direct effect on college persistence. Some researchers have suggested that the linkage of financial aid to admission strategies is a crucial enrollment management concept (St. John, 1991). This could have particular impact on minority enrollment strategies.

The current struggle to improve the attainments of minority and lowincome students comes at a time of increased fiscal pressures in institutions of higher education. Given that state and federal appropriations for higher education have stayed about the same over the past few years, institutions have compensated for the lack of increased government support by increasing tuition. This also has the effect of limiting access to those students who can afford to pay for college. Since minority families tend to have lower incomes than white families (Baker and Vélez, 1991), institutions that strive to make their programs affordable are providing opportunities for increased access and attainment.

\section{Implications}

The key areas for minority-student college persistence are academic preparation, adequate financial aid, and strong support networks in college. In years of research on minority students, we have learned quite a lot about the challenges endured by underrepresented populations. However, gaps remain in persistence rates.

Recent research studies on student persistence and minority students have utilized complex statistical techniques and large sample sizes, helping tease out the complexities among the groups and clarify how persistence rates may be differentially affected by similar interventions. It is important that researchers and practitioners continue to design interventions that affect particular populations. Finding best practices for all students may not be serving all students.

Inadvertent discrimination may hinder minority students' progress and may negatively affect their persistence. In the Indiana state study, controlling for preparation, college grades, and remedial courses, African 
Americans with majors in business, education, health, and computer science did not persist as well as their peers with undeclared majors. The causes cannot be explained solely by the lack of parental education or low achievement. An atmosphere of inadvertent discrimination may be the case in this state's higher education. The fact that African Americans in several applied majors do not persist as well as their peers with undeclared majors reveals there may be a serious problem with the engagement of the best and brightest minority students. Previous literature has found that minority students do not feel comfortable in college environments that lack diversity. Environments that make minority students feel less than fully human (Feagin, Vera, and Imani, 1996) may be additionally problematic for persistence.

Indiana may not be alone in facing the challenge of improving opportunities for persistence by high-achieving minority students. Indeed, this is the first state-level study to explore the role of preparation and achievement for a cohort of students within a state. It is possible that if other states take the steps to compile longitudinal databases, they too will find serious challenges that impede the academic success of their students.

The results of the Indiana state study show that public finance policies do influence different groups in different ways. Because of their high poverty rate in the state, African Americans can benefit from the state's achievement program more than whites. Further, excessive loans can be problematic for middle-income families, who may question whether their expected earnings will grow sufficiently to justify continued borrowing. At the very least, these differences merit further and wider consideration, given the ongoing challenges facing educational opportunity for high-achieving students of color. When adequate financial aid is provided, parents' education is not the barrier for African Americans and Hispanics that it is for whites. The study findings suggest that the main challenge in providing access to college is creating engaging curriculum.

A final area of implication is that of institutional considerations. Swail, Redd, and Perna (2003) describe ten "essential factors" for establishing retention programs. Key among them are that institutions need to "rely on proven research," "support institutional research in the monitoring of programs and students," and "be sensitive to students' needs and target the most needy student populations" (pp. 116-118).

As we move into the second decade of the twenty-first century, more dramatic changes in institutional policy and practice may be needed to continue to improve student retention. Campus leaders need to remain committed to solving the problem of differential rates of persistence by underrepresented minority students. Uniting research and practice and targeting underrepresented populations with appropriate interventions will help campuses develop strong retention programs and will be the key to increasing the participation of minority students in higher education. 


\section{References}

Advisory Committee on Student Financial Assistance. Empty Promises: The Myth of College Access in America. Washington, D.C.: Advisory Committee on Student Financial Assistance, 2002.

Allen, W. R. "The Color of Success: African-American College Student Outcomes at Predominantly White and Historically Black Public Colleges and Universities." Harvard Educational Review, 1992, 62(1), 26-43.

Allen, W. R., Bonous-Hammarth, M., and Suh, S. A. "Who Goes to College? High School Context, Academic Preparation, the College Choice Process, and College Attendance." In E. P. St. John (ed.), Readings on Equal Education. Vol. 20: Improving Access and College Success for Diverse Students: Studies of the Gates Millennium Scholars Program. New York: AMS Press, 2004.

Astin, A. W. What Matters in College: Four Critical Years Revisited. San Francisco: JosseyBass, 1993.

Astin, A. W., Tsui, L., and Avalos, J. Degree Attainment Rates at American Colleges and Universities: Effects of Race, Gender, and Institutional Type. Los Angeles: Higher Educational Research Institute, University of California, 1996.

Baker, T. L., and Vélez, W. "Access To and Opportunity in Postsecondary Education in the United States: A Review." Sociology of Education, 1991, Extra Issue, 82-101.

Bean, J. P. "Dropouts and Turnover: The Synthesis and Test of a Causal Model of Student Attrition." Research in Higher Education, 1980, 12, 155-187.

Bean, J. P., and Eaton, S. B. "A Psychological Model of College Student Retention." In J. M. Braxton (ed.), Reworking the Student Departure Puzzle. Nashville, Tenn.: Vanderbilt University Press, 2000.

Berger, J. B. "Optimizing Capital, Social Reproduction, and Undergraduate Persistence: A Sociological Perspective." In J. M. Braxton (ed.), Reworking the Student Departure Puzzle. Nashville, Tenn.: Vanderbilt University Press, 2000.

Bonous-Hammarth, M. "Value Congruence and Organizational Climates for Undergraduate Persistence." In J. C. Smart (ed.), Higher Education: A Handbook of Theory and Research, vol. 15. New York: Agathon Press, 2000.

Boudreau, C., and Kromrey, J. "A Longitudinal Study of Retention and Academic Performance of Participants in a Freshman Orientation Course." Journal of College Student Development, 1994, 35, 444-449.

Braxton, J. M. (ed.). Reworking the Student Departure Puzzle. Nashville, Tenn.: Vanderbilt University Press, 2000.

Braxton, J. M., Sullivan, A. S., and Johnson, R. M. "Appraising Tinto's Theory of College Student Departure." In John C. Smart (ed.), Higher Education: Handbook of Theory and Research, vol. 12. New York: Agathon Press, 1997.

Bynum, J. E., and Thompson, W. F. "Dropouts, Stopouts and Persisters: The Effects of Race and Sex Composition of College Classes." College and University, 1983, 59(1), 39-48.

Cabrera, A. F., Stampen, J. O., and Hansen, W. L. "Exploring the Effects of Ability to Pay on Persistence in College." Review of Higher Education, 1990, 13(3), 303-336.

Carter, D. F. "The Impact of Institutional Choice and Environments on African American and White Students' Degree Expectations." Research in Higher Education, 1999, 40, $17-41$.

DesJardins, S. L., Ahlburg, D. A., and McCall, B. P. "A Temporal Investigation of Factors Related to Timely Degree Completion." Journal of Higher Education, 2002, 73(5), 555-581.

Durkheim, E. Suicide. (J. A. Spaulding and G. Simpson, trans.). Glencoe, Ill.: The Free Press, 1951.

Feagin, J. R., Vera, H, and Imani, N. The Agony of Education: Black Students at White Colleges and Universities. New York: Routledge, 1996. 
Getzlaf, S. B., Sedlacek, G. M., Kearney, K. A., and Blackwell, J. M. "Two Types of Voluntary Undergraduate Attrition: Application of Tinto's Model." Research in Higher Education, 1984, 20(3), 257-268.

Hanson, S. L. "Lost Talent: Unrealized Educational Aspirations and Expectations Among U.S. Youths." Sociology of Education, 1994, 67, 159-183.

Hartle, T. W. "Clueless About College Costs." Presidency, 1998, 1(1), 20-27.

Hatch, L. R., and Mommsen, K. "The Widening Gap in American Higher Education." Journal of Black Studies, 1984, 14(4), 457-476.

Hearn, J. C. "The Relative Roles of Academic, Ascribed, and Socioeconomic Characteristics in College Destinations." Sociology of Education, 1984, 57, 22-30.

Hearn, J. C. "Academic and Nonacademic Influences on the College Destinations of 1980 High School Graduates.” Sociology of Education, 1991, 64(July), 158-171.

"Holding a Four-Year College Degree Brings Blacks Close to Economic Parity with Whites." Journal of Blacks in Higher Education, 47. http://www.jbhe.com/news_views/ 47_four-year_collegedegrees.html. Accessed June 1, 2005.

Hurtado, S. "Linking Diversity and Educational Purpose: How Diversity Affects the Classroom Environment and Student Development." In G. Orfield (ed.), Diversity Challenged: Evidence on the Impact of Affirmative Action. Cambridge, Mass.: Harvard Publishing Group, 2001.

Hurtado, S., Carter, D. F., and Spuler, A. "Latino Student Transition to College: Assessing Difficulties and Factors in Successful College Adjustment." Research in Higher Education, 1996, 37(2), 135-157.

Hurtado, S., Milem, J. F., Clayton-Pederson, A. R., and Allen, W. R. "Enhancing Campus Climates for Racial/Ethnic Diversity: Educational Policy and Practice." The Review of Higher Education, 1998, 21(3), 279-302.

Kaltenbaugh, L. S., St. John, E. P., and Starkey, J. B. "What Difference Does Tuition Make? An Analysis of Ethnic Differences in Persistence." Journal of Student Financial Aid, 1999, 29(2), 21-31.

Keller, G. "The New Demographics of Higher Education." The Review of Higher Education, 2001, 24(3), 219-235.

Kuh, G. "The Other Curriculum: Out-of-Class Experiences Associated with Student Learning and Personal Development." Journal of Higher Education, 1995, 66, $123-155$.

Lavin, D. E., and Crook, D. B. "Open Admissions and Its Outcomes: Ethnic Differences in Long-Term Educational Attainment." American Journal of Education, 1990, 98(4), 389-425.

Malveaux, J. What's at Stake: The Social and Economic Benefits of Higher Education. Challenging Times, Clear Choices: An Action Agenda for College Access and Success. National Dialogue on Student Financial Aid, Research Report no. 2. Washington, D.C.: Pathways to College Network, 2003.

Mehan, H., Hubbard, L., and Villanueva, I. "Forming Academic Identities: Accommodation Without Assimilation Among Involuntary Minorities." Anthropology of Education Quarterly, 1994, 25, 91-117.

Myers, R. D. College Success Programs: Executive Summary. Washington, D.C.: Pathways to College Network, 2003.

Pascarella, E. T., Smart, J. C., and Smylie, M. A. "College Tuition Costs and Early Career Socioeconomic Achievement: Do You Get What You Pay For?" Higher Education, 1992, 24(3), 275-291.

Pascarella, E. T., and Terenzini, P. T. "Predicting Freshman Persistence and Voluntary Dropout Decisions from a Theoretical Model." Journal of Higher Education, 1980, 51(1), 60-75.

Pascarella, E. T., and Terenzini, P. T. How College Affects Students: Findings and Insights from Twenty Years of Research. San Francisco: Jossey-Bass, 1991. 
Pascarella, E. T., and Terenzini, P. T. "Studying College Students in the 21st Century: Meeting New Challenges." The Review of Higher Education, 1998, 21(2), 151-165.

Pathways to College Network. "A Shared Agenda: A Leadership Challenge to Improve College Access and Success." Washington, D.C.: Pathways to College Network, 2003.

Paulsen, M. B., and St. John, E. P. "Social Class and College Costs: Examining the Financial Nexus Between College Choice and Persistence." Journal of Higher Education, 2002, 73(3), 189-236.

St. John, E. P. "Changes in Pricing Behavior During the 1980s: An Analysis of Selected Case Studies." Journal of Higher Education, 1991, 63(2), 165-187.

St. John, E. P. Prices, Productivity, and Investment: Assessing Financial Strategies in Higher Education. ASHE-ERIC Higher Education Report, no. 3. Washington, D.C.: George Washington University, 1994.

St. John, E. P., Carter, D. F., Chung, C. G., and Musoba, G. D. "Diversity and Persistence in Indiana Higher Education: The Impact of Preparation, Major Choices, and Student Aid." In E. P. St. John (ed.), Readings on Equal Education. Vol. 21: Public Policy and Educational Opportunity: School Reforms, Postsecondary Encouragement, and State Policies on Higher Education. New York: AMS Press, 2006.

St. John, E. P., Paulsen, M. B., and Carter, D. F. "Diversity, College Costs, and Postsecondary Opportunity: An Examination of the College Choice-Persistence Nexus for African Americans and Whites." Journal of Higher Education, 2005, 76, 545-569.

St. John, E. P., Paulsen, M. B., and Starkey, J. B. "The Nexus Between College Choice and Persistence." Research in Higher Education, 1996, 37, 175-220.

Shom, C., and Spooner, S. E. "Minority Access to Higher Education: The Precollegiate Program." NASPA Journal, 1990, 27(3), 222-228.

Smedley, B. D., Myers, H. F., and Harrell, S. P. "Minority-Status Stresses and the College Adjustment of Ethnic Minority Freshmen." Journal of Higher Education, 1993, 64(4), 434-452.

Spady, W. G. "Dropouts from Higher Education: An Interdisciplinary Review and Synthesis." Interchange, 1970, 1(1), 64-85.

Spady, W. G. "Dropouts from Higher Education: Toward an Empirical Model." Interchange, 1971, 2(3), 38-62.

Stewart, D. M. "Overcoming the Barriers to Successful Participation by Minorities." Review of Higher Education, 1988, 11(4), 329-335.

Swail, W. S., Redd, K. E., and Perna, L. A. Retaining Minority Students in Higher Education: A Framework for Success. ASHE-ERIC Higher Education Report, vol. 30, no. 2. San Francisco: Jossey-Bass, 2003.

Thomas, G. E. "The Future of Blacks in Higher Education: Recommendations and Conclusions." In G. E. Thomas (ed.), Black Students in Higher Education: Conditions and Experiences in the 1970s. Westport, Conn.: Greenwood Press, 1981.

Tierney, W. G. "An Anthropological Analysis of Student Participation in College." Journal of Higher Education, 1992, 63(6), 603-618.

Tinto, V. "The Limits of Theory and Practice in Student Attrition." Journal of Higher Education, 1982, 53, 687-700.

Tinto, V. Leaving College: Rethinking the Causes and Cures of Student Attrition (2nd ed.). Chicago: University of Chicago Press, 1993.

Turner, C.S.V. "Guests in Someone Else's House: Students of Color." The Review of Higher Education, 1994, 17(4), 355-370.

DEBORAH FAYE CARTER is associate professor of education and director of the Center for the Study of Higher and Postsecondary Education at the University of Michigan School of Education. 